Socialist Studies / Études socialistes 6(2) Fall 2010: 160-172

Copyright (C) 2010 The Author(s)

SPECIAL SECTION ON ROSA LUXEMBURG'S POLITICAL ECONOMY

\title{
Rosa Luxemburg and the Global Violence of Capitalism
}

\author{
PAUL LE BLANC \\ Department of History and Political Science, LaRoche College. Pittsburgh, Pennsylvania, \\ United States
}

\begin{abstract}
:
Rosa Luxemburg's pungent honesty is evident in her critical-minded and 'unorthodox' analysis of the economic expansionism of imperialism that arose out of the accumulation of capital. Despite an idiosyncratic reading and critique of Marx's Capital, she sought to defend and advance the revolutionary perspectives of classical Marxism. Criticisms and counterpoised analyses offered by Rosdolsky, Bukharin, Lenin, and Robinson have not diminished what are generally seen as brilliant contributions. Militarism, war, and inhumanity are perceived as essential to imperialism in her analyses, and imperialism is seen as central to the nature of capitalism. Luxemburg's account of global economic development reflect impressive economic insight, historical sweep, and anthropological sensitivity that impress critics as well partisans.

\section{Résumé :}

Le franc parler de Rosa Luxemburg est évident dans ses analyses critiques et 'hétérodoxes' de l'expansionnisme économique de l'impérialisme qui a émergé de l'accumulation du capital. Malgré une lecture idiosyncratique et critique du Capital de Marx, elle cherchait à défendre et à avancer les perspectives révolutionnaires du marxisme classique. Les critiques et contre-analyses offertes par Rosdolsky, Boukharine, Lénine et Robinson n'ont pas diminué des contributions communément admises comme brillantes. Dans ses analyses, le militarisme, la guerre et l'inhumanité sont perçues comme essentiels à l'impérialisme et l'impérialisme occupe une place centrale dans la nature du capitalisme. La description du développement économique mondial par Luxemburg montre une acuité économique impressionnante, un sens de l'histoire, et une sensitivité anthropologique qui ont impressionné ses critiques comme ses partisans.
\end{abstract}

\section{Keywords}

capitalism • economics • imperialism • Marxism • socialism

Paul Le Blanc is professor of history at La Roche College. He has written books on Marx, Gramsci, Lenin and Luxemburg, among others, as well as on the working class history of the United States. Recent publications include articles and reviews in Historical Materialism, International Labor and Working Class History, International Viewpoint, Labour/Le Travail, Monthly Review, New Politics and Working USA. He may be reached at La Roche College, Pittsburg, PA 15237, United States.

Paul Le Blanc est professeur d'histoire à La Roche College. Il a écrit des livres sur Marx, Gramsci, Lénine et Luxemburg, entre autres, ainsi que sur l'histoire de la classe ouvrière aux Etats-Unis. Parmi ses publications récentes on trouve des articles et des critiques de livres dans Historical Materialism, International Labor and Working Class History, International Viewpoint, Labour/Le Travail, Monthly Review, New Politics, Working USA. II peut être joint à La Roche College, Pittsburg, PA 15237, Etats-Unis.

Socialist Studies: the Journal of the Society for Socialist Studies/Études socialistes: Revue de la Société d'études socialistes www.socialiststudies.com 
LE BLANC: Rosa Luxemburg and the Global Violence of Capitalism

\section{Mots-clés}

capitalisme $\bullet$ économie $\bullet$ impérialisme $\bullet$ marxisme $\bullet$ socialisme

Rosa Luxemburg sought to keep her balance - as any serious revolutionary must - with a pungent honesty and a lively sense of humor.

By the time she was in her mid-forties, she confessed to an intimate friend that 'in theoretical work as in art, I value only the simple, the tranquil and the bold. This is why, for example, the famous first volume of Marx's Capital, with its profuse rococo ornamentation in the Hegelian style, now seems an abomination to me (for which, from the Party standpoint, [Luxemburg joked] I must get 5 years' hard labor and 10 years' loss of civil rights....).' She hastened to add that Marx's economic theories were the bedrock of her own theoretical work, but also emphasized that her 'more mature' work was in 'its form...extremely simple, without any accessories, without coquetry or optical illusions, straightforward and reduced to the barest essentials; I would even say 'naked,' like a block of marble.'

Delving into theoretical questions -- explaining the economic expansionism of imperialism that arose out of the accumulation of capital, which became the title of her 1913 classic -- was a creative labor through which 'day and night I neither saw nor heard anything as that one problem developed beautifully before my eyes.' The process of thinking -- as she slowly paced back and forth, 'closely observed by [her cat] Mimi, who lay on the red plush tablecloth, her little paws crossed, her intelligent head following me' -- and the actual process of writing combined as an experience of trance-like and profound pleasure (Bonner 1993, 185, 204).1

Yet this was someone for whom -- despite her banter about Hegel -dialectical thinking came most naturally. Applying the dialectical approach to her economic studies, Luxemburg understood capitalism as an expansive system driven by the dynamic of accumulation. Capital in the form of money is invested in capital in the form of raw materials and tools and labor-power, which is transformed -- by the squeezing of actual labor out of the labor-power of the workers -- into capital in the form of the commodities thereby produced, whose increased value is realized through the sale of the commodities for more money than was originally invested, which is the increased capital out of which the capitalist extracts his profits,

\footnotetext{
${ }^{1}$ Roman Rosdolsky, while agreeing with Georg Lukács that she was 'a genuine dialectician,' comments that Luxemburg 'sometimes overlooked the dialectical content hiding behind Marx's "Hegelian style,"' resulting in a lack of understanding of Marx's methodology in Capital that led to her own flawed critique of that work (Rosdolsky 1989, 492-493).
} 
only to be driven to invest more capital for the purpose of achieving ever greater capital accumulation.

Luxemburg's analysis of the capital accumulation process involves a complex (for some, an overly-complex) critique of the second volume of Marx's Capital. According to Luxemburg, there is a methodological problem with how Marx approaches the analysis of capitalism - creating what she sees as an insoluble contradiction. Marx, she asserts, posits an abstract individual capitalist, rather than the actual 'aggregate social capital,' and he also posits an abstract society composed only of capitalists and workers; she also castigates Marx's 'reproduction schemes' (showing the relationship of capital goods used for industrial production and consumer goods) in that second volume, scoffing at the notion that 'this untiring merry-go-round in thin air could be a faithful reflection in theory of capitalist reality' (Luxemburg 1951, 335).

Not all have been charmed by such alluring irreverence. Roman Rosdolsky in his magisterial The Making of Marx's 'Capital' (1989) argues that Luxemburg (along with many other would-be Marxists of that time) failed to comprehend the complexity and sophistication of Marx's method in Capital. Specifically, she missed the fact that the first two volumes of Capital 'do not go beyond the analysis of 'capital in general' whereas the third volume does and therefore represents the transition to the analysis of 'many capitals' and there interaction with one another, i.e. capital 'in its reality". In fact, Rosdolsky insists, her analysis suffered from a 'complete neglect of Marx's category of "capital in general"' and its role in the abstraction of 'a pure capitalist society' which yield a far richer analysis than Luxemburg's assumptions allow for. According to Rosdolsky, 'the 'bloodless fiction' for which Luxemburg rebukes Marx is none other than the study of the social reproduction process in the context of 'capital in general' (1989 66-67, 67, 71).

Yet even one of her severest critics, the Russian Marxist Nikolai Bukharin, hailed Luxemburg's analysis as 'a daring theoretical attempt' and 'the deed of a brilliant theoretical intellect' (Bukharin 1972,268). This refers to what Rosdolsky himself praises as 'the valid kernel of her book,' $(1989,72)$ The Accumulation of Capital (1951, first published 1913). Her resolution of what she considered to be problems of Marx's analysis involved focusing on the global dynamics of the capitalist system and arguing that a voracious imperialism, along with its handmaidens militarism and war, are at the heart of capitalist development. As Harry Magdoff once put it, 'imperialism is not a matter of choice for a capitalist society; it is the way of life of such a society' $(1969,26)$. This was in 
dramatic contrast to the optimistic gradualism of such reformists as Eduard Bernstein whose 'revisionist' perspectives, challenging Marx's revolutionary theories, had gained considerable influence in the socialist movement. But it was also in contrast to the 'orthodox' Marxism personified by Karl Kautsky - who increasingly propagated a somewhat static understanding of Marx's perspective while inclined to see imperialism in terms far less grim than Luxemburg would allow for.

Luxemburg offers an incisive economic analysis of imperialism. There are several distinctive features of Luxemburg's analysis that sets it off from that of other leading Marxist theorists - Rudolf Hilferding, Nikolai Bukharin, and V.I. Lenin. She makes a great deal of the co-existence in the world of different cultures, different types of society, and different modes of production (or forms of economy - different economic systems). Historically the dominant form of economy worldwide was the communal hunting and gathering mode of production, which was succeeded in many areas by a more or less communistic agricultural form of economy which she characterized as a primitive 'peasant economy.' This was succeeded in some areas by non-egalitarian societies dominated by militarily powerful elites, constituting modes of production that she labeled 'slave economy' and 'feudalism.' Sometimes co-existing with, sometimes superseding these was a 'simple commodity production' in which artisans and farmers, for example, would produce commodities for the market in order to trade or sell for the purpose of acquiring other commodities that they might need or want. This simple commodity mode of production is different from the capitalist mode of production, which is driven by the already-described capital accumulation process, overseen by an increasingly wealthy and powerful capitalist minority (Luxemburg 1951, 325, 368-9).

Three features especially differentiate the analysis in The Accumulation of Capital from the perspectives of other prominent Marxists:

1) Luxemburg advances a controversial conceptualization of imperialism's relationship to the exploitation of the working class in the advanced capitalist countries. Because workers receive less value than what they create, they are unable to purchase and consume all that is produced. This under-consumption means that capitalists must expand into non-capitalist areas, seeking markets as well as raw materials and investment opportunities (particularly new sources of labor) outside of the capitalist economic sphere.

' Non-capitalist organizations provide a fertile soil for capitalism,' she noted, which means that 'capital feeds on the ruins of such 
organizations, and, although this non-capitalist milieu is indispensable for accumulation, the latter proceeds, at the cost of this medium nevertheless, by eating it up'. Penetration into non-capitalist economies facilitate the capital accumulation process, but capitalist accumulation 'corrodes and assimilates' these economies. This constituted a new contradiction: 'capital cannot accumulate without the aid of non-capitalist organizations, nor, on the other hand, can it tolerate their continued existence side by side with itself. Only the continuous and progressive disintegration of noncapitalist organizations makes accumulation of capital possible'. The inevitable tendency this leads to will be 'the standstill of accumulation,' which 'means that the development of the productive forces is arrested,' leading to capitalist collapse (Luxemberg 1951, 416, 417). (We will see that Luxemburg did not conceive of this leading to a painless transition to socialism, but rather to the desperate escalation of militarism and war.)

2) Another distinctive quality of her conceptualization of imperialism is that it is not restricted to 'the highest stage' or 'latest stage' of capitalism. Rather, imperialism is something that one finds at the earliest beginnings of capitalism - in the period of what Marx calls 'primitive capitalist accumulation' - and which continues non-stop, with increasing and overwhelming reach and velocity, down to the present. Or as she puts it, 'capitalism in its full maturity also depends in all respects on non-capitalist strata and social organizations existing side by side with it,' and 'since the accumulation of capital becomes impossible in all points without non-capitalist surroundings, we cannot gain a true picture of it by assuming the exclusive and absolute domination of the capitalist mode of production'. Quoting Marx, she concluded: 'The historical career of capitalism can only be appreciated by taking them together. "Sweating blood and filth with every pore from head to toe" characterizes not only the birth of capital but also its progress in the world at every step, arid thus capitalism prepares its own downfall under ever more violent contortions and convulsions'. This meant, on the international arena, 'colonial policy, an international loan system -- a policy of spheres of interest -- and war. Force, fraud, oppression, looting are openly displayed without any attempt at concealment, and it requires an effort to discover within this tangle of 
political violence and contests of power the stern laws of the economic process' (Luxemburg 1951, 364-5, 452-3). ${ }^{2}$

3) Another special feature of Luxemburg's contribution is her anthropological sensitivity to the impact of capitalist expansion on the rich variety of the world's peoples and cultures that one cannot find in the key works of Hilferding, Lenin, and Bukharin.

The survey of capitalist expansionism's impact in her Accumulation of Capital includes such examples as:

- the destruction of the English peasants and artisans;

- the destruction of the native-American peoples (the so-called Indians);

- the enslavement of African peoples by the European powers;

- the ruination of small farmers in the mid-western and western regions of the United States;

- the onslaught of French colonialism in Algeria;

- the onslaught of British colonialism in India;

- British incursions into China, with special reference to the Opium wars;

- the onslaught of British colonialism in South Africa (with lengthy reference to the three-way struggle of black African peoples, the Dutch Boers, and the British).

'Each new colonial expansion is accompanied, as a matter of course, by a relentless battle of capital against the social and economic ties of the natives,' she wrote, 'who are also forcibly robbed of their means of production and labor power.' Observing that 'from the point of view of the primitive societies involved, it is a matter of life or death,' she noted that the invariable consequence involved 'permanent occupation of the colonies by the military, native risings and punitive expeditions are the order of the day for any colonial regime.' The economic underpinnings of such realities was always emphasized: 'Their means of production and their labor power no less than their demand for surplus products is necessary to capitalism,' Luxemburg wrote. 'Yet the latter is fully determined to undermine their independence as social units, in order to gain possession of their means of

\footnotetext{
${ }^{2}$ While the English translation of Luxemburg's book makes reference to Chapter XXIV of Capital, it is part VIII (Chapters XXVI to XXXIII) in which one finds discussion of 'primitive accumulation' in Marx (1967).
} 
Socialist Studies / Études socialistes 6(2) Fall 2010: 160-172

production and labor power and to convert them into commodity buyers.' But the destructive impact of all this on the cultures of the world's peoples was emphasized by Luxemburg as by no other Marxist theorist of her time: 'The unbridled greed, the acquisitive instinct of accumulation must by its very nature take every advantage of the conditions of the market and can have no thought for the morrow. It is incapable of seeing far enough to recognize the value of the economic monuments of an older civilization' (Luxemburg 1951, 370, 371, 372, 376).

These strengths in Luxemburg's analysis were drawn together, two years later, in the eloquent anti-war polemic composed from a prison cell:

Capitalist desire for imperialist expansion, as the expression of its highest maturity in the last period of its life, has the economic tendency to change the whole world into capitalistically producing nations, to sweep away all superannuated, pre-capitalistic methods of production and society, to subjugate all the riches of the earth and all means of production to capital, to turn the laboring masses of all zones into wage slaves. In Africa and in Asia, from the most northern regions to the southernmost point of South America and the South Seas, the remnants of old communistic social groups, of feudal society, of patriarchal systems, and of ancient handicraft production are destroyed and stamped out by capitalism. Whole peoples are destroyed, ancient civilizations are leveled to the ground, and in their place profiteering in its most modern forms is being established.

This brutal triumphant procession of capitalism through the world, accompanied by all the means of force, of robbery, and of infamy, has one bright phase: it has created the premises for its own final overthrow, it has established the capitalist world rule which, alone, the socialist world revolution can follow. This is the only cultural and progressive aspect of the great so-called works of culture that were brought to the primitive countries. To capitalist economists and politicians, railroads, matches, sewerage systems, and warehouses are progress and culture. Of themselves such works, grafted upon primitive conditions are neither culture nor progress, for they too dearly paid for with the sudden economic and cultural ruin of the peoples who must drink down the bitter cup of misery and horror of two social orders, of traditional agricultural landlordism, of super-modern, super-refined capitalist exploitation, at one and the same time (Luxemburg 1970, 325). 
As suggested above, it can be argued that capitalism is more complex, more dynamic than Luxemburg allows. ${ }^{3}$ Beyond this, there is more truth than she seems aware in her assertion that 'the accumulation of capital, as an historical process, depends upon non-capitalist social strata and forms of social organization.' Non-capitalist regions of the globe are certainly the target of capitalist penetration and degradation for the sake of maximizing profits - but such penetration is also relentlessly taking place in the multifaceted non-capitalist aspects of our lives and environment, within highly developed capitalist countries. The destructive profiteering expansion not only into the cultures and lives of people in economically 'under-developed' economies but also into the cultures of lives of people who live highly developed economies. 'Capital needs the means of production and the labor power of the whole globe for untrammeled accumulation,' Luxemburg wrote. 'It cannot manage without the natural resources and the labor power of all territories' (1951, 365-366). This is true of all territories indeed, including the territories of our bodies, our family life, our friendships, our creative drives, our sexuality, our dreams, and multiple community and social and cultural activities -- all of which are permeated by pre-capitalist and non-capitalist dimensions and energies even in expanding global regions where an advanced capitalist economy predominates.

Indeed, in perhaps a less comprehensive way, elements of such understanding informed earlier critics of Luxemburg's analysis. In 1924 Nikolai Bukharin, one of the outstanding economists in the newly-arisen world Communist movement (before its bureaucratic-authoritarian degeneration had fully crystallized), noted that - as Luxemburg herself insisted - 'capitalism was already conducting ravening colonial policies at a very early stage of its development.' But inside of the capitalist countries, during this early period, there were still plentiful "non-capitalist' sectors of the population - 'peasants, small craftsmen, etc. What need was there to wander to distant lands? ... Resting on the ground of her own theory, Rosa Luxemburg cannot possibly answer this question'. Bukharin went on to insist that capital, 'in hunting for maximum profits, ... looks for cheaper labor and, at the same time, the highest rate of exploitation' (Bukharin 1972, 248).

Luxemburg's very definition of imperialism was challenged. 'Imperialism is the political expression of the accumulation of capital,' she

\footnotetext{
${ }^{3}$ See Rosdolsky (1989, 63-72, but especially 66-67). An excellent discussion can also be found in Kowalik (1990, 247-253). Worth consulting, as well is Howard and King $(1989,106-115)$.
} 
Socialist Studies / Études socialistes 6(2) Fall 2010: 160-172

wrote, 'in its competitive struggle for what remains still open for the noncapitalist environment' (Luxemburg 1951, 446). Exclaiming that 'here we are faced with a whole pile of various mistakes,' Bukharin elaborated:

Firstly, capital has always fought for 'remains' (a more than unprecise term). Secondly, it follows from this definition that a fight for territories that have already become capitalist is not imperialism, which is utterly wrong. Thirdly, it follows from the same definition that a fight for already 'occupied' territories is not imperialism either. Again, this factor of the definition is utterly wrong. The whole definition suffers from the basic fault that it treats the whole problem without any regard to the necessity of a specific characterization of capital as finance capital (Bukharin 1972, 253).

This last comment alludes to the more expansive analysis of imperialism developed by Russia's revolutionary Marxists - the Bolsheviks (above all Bukharin himself as well as Vladimir Ilyich Lenin) - in the early years of World War I. 'Imperialism is a policy of conquest,' Bukharin had insisted in his 1915 work Imperialism and World Economy. 'But not every policy of conquest is imperialism. That is why, when we speak of imperialism as the policy of finance capitalism, its conquest character is self-understood; at the same time, however, we point out what production relations are being reproduced by this policy of conquest.' Bukharin added that 'we imply highly developed organisms and, consequently, a certain scope and intensity of world relations; in a word, we imply the existence of a developed world economy; by the same token we imply a certain state of production relations, of organizational forms of the economic life, a certain interrelation of classes, and also a certain future of economic relations, etc., etc.' (Bukharin 1972a, 114-5). In his 1916 work Imperialism, the Highest Stage of Capitalism, Lenin offered a conception no less multi-faceted, involving 'the capitalist threads, which in thousands of different intercrossings' bind the global economy 'into an instrument for oppressing a thousand million people (in the colonies and semi-colonies), that is, more tan half the population of the globe that inhabits the dependent countries, as well as the wage-slaves of capital in the 'civilized' countries' (Lenin 2008, 237) 4

Given that her Accumulation of Capital appeared in 1913, that her Anti-Critique defense was composed while she was in prison in 1915, and

\footnotetext{
${ }^{4}$ This quote from Lenin is from a 1920 preface to the French and German editions of Lenin's work.
} 
that she was killed by right-wing death squads at the beginning of 1919 , Luxemburg had no opportunity to consider these contributions by Lenin and Bukharin. Her polemics were not aimed at fellow revolutionaries in Russia or elsewhere. Rather, she was contending with elements in the socialist movement who believed negative features of capitalism could gradually be reformed away, as well as those self-defined 'orthodox Marxists' who veered away from revolutionary commitments.

Paul Sweezy shrewdly cites Luxemburg's comment that a conception of 'limitless of capital accumulation' will mean that 'the sold soil of objective historical necessity is cut from under the feet of socialism' (Sweezy 1968, 207). Her analytical preference tilted her toward the notion that not only were non-capitalist portions of the globe necessary for the accumulation process, but that once these were inevitably incorporated into the global capitalist economy, the accumulation process would break down - propelling the laboring masses to socialist revolution. It cannot be denied, however, that the tendency of 'limitless capital accumulation,' although rejected by Luxemburg, has asserted itself in ways that dramatically undermined the revolutionary socialist outcomes that she anticipated.

Regardless of powerful criticisms leveled at Luxemburg's Accumulation of Capital, her discussion of the workings and impacts of imperialism clearly retain considerable validity. Modern economist Joan Robinson once commented, after an extremely critical survey of The Accumulation of Capital, that 'for all of its confusions and exaggerations, this book shows more prescience than any orthodox contemporary could claim' (Robinson 1951, 28). ${ }^{5}$

The importance of foreign investment and foreign aid, the process of 'modernization,' the role of the World Bank and International Monetary Fund, are all anticipated in her discussion of 'international loans.' Noting the dramatic increase in 'the world-wide movement of capital, especially in Asia and neighboring Europe: in Russia, Turkey, Persia, India, Japan, China, and also in North Africa,' she observed that economically developing areas - particularly newly independent countries - become targets for foreign

\footnotetext{
${ }^{5}$ Robinson (1951) felt that Luxemburg 'garbles' and 'brushes away' aspects of Marx's argument, is too prone to treat some economists 'with a good deal of sarcasm' and to 'dismiss them as useless,' also complaining that she 'neglects the rise of real wages,' focuses too exclusively on economic imperialism as the source of capital accumulation, and that in general Luxemburg's 'argument streams along bearing a welter of historical examples in its flood, and ideas emerge and disappear again bewilderingly' $(20,22,28)$
} 
Socialist Studies / Études socialistes 6(2) Fall 2010: 160-172

loans that while indispensable for the emancipation of the rising capitalist states ... are yet the surest ties by which the old capitalist states maintain their influence, exercise financial control and exert pressure on the customs, foreign and commercial policy of the young capitalist states.' Luxemburg observed that modernization schemes, such as railroad construction, irrigation projects, etc., 'almost exclusively served the purposes of an imperialist policy, of economic monopolization and economic subjugation of the backward communities,' devastating the original economic and cultural patterns and relationships, drawing increasing numbers of people into the embrace of the capitalist market. She also observed that 'there was an element of usury in every loan, anything between one-fifth and one-third of the money ostensibly lent sticking to the fingers of the European bankers.' Asking 'how-where were the means to come from' that would pay off the mounting debts, she pointed to the intensifying exertions and rising tax burdens of the peasant masses and laboring poor. 'Although it became evident at every step that there were technical limits to the employment of forced labor for the purposes of modern capital, yet this was amply compensated by capital's unrestricted power of command over the pool of labor power, how long and under what conditions men were to work, live and be exploited' (Luxemburg 1951, 419-20, 421, 434, 435).

No less dramatic is her perception of the economic role of militarism in the globalization of the market economy:

Militarism fulfils a quite definite function in the history of capital, accompanying as it does every historical phase of accumulation. It plays a decisive part in the first stages of European capitalism, in the period of the socalled 'primitive accumulation', as a means of conquering the New World and the spice-producing countries of India. Later, it is employed to subject the modern colonies, to destroy the social organizations of primitive societies so that their means of production may be appropriated, forcibly to introduce commodity trade in countries where the social structure had been unfavorable to it, and to turn the natives into a proletariat by compelling them to work for wages in the colonies. It is responsible for the creation and expansion' of spheres of interest for European capital in non-European regions, for extorting railway concessions in backward countries, and for enforcing the claims of European capital as international lender. Finally, militarism is a weapon in the competitive struggle between capitalist countries for areas of non-capitalist civilization (Luxemburg 1951, 454). 
LE BLANC: Rosa Luxemburg and the Global Violence of Capitalism

But more than this, military spending 'is in itself a province of accumulation,' making the modern state a primary 'buyer for the mass of products containing the capitalized surplus value,' although in fact - in the form of taxes -- 'the workers foot the bill' (Luxemburg 1951, 455).

In fact, the workers 'foot the bill' of militarism in more ways than one - which Luxemburg emphasized in her 1915 Junius Pamphlet, noting that 'the world war is a turning point in the course of imperialism,' when 'for the first time, the destructive beasts that have been loosed by capitalist Europe over all other parts of the world have sprung, with one awful leap, into the midst of the European nations.' Integral to this was 'the mass destruction of the European proletariat. ... Millions of human lives were destroyed in the Vosges, in the Ardennes, in Belgium, Poland, in the Carpathians and on the Save; millions have been hopelessly crippled. But nine-tenths of these millions come from the ranks of the working class of the cities and the farms. It was our strength, our hope that was mowed down there day after day, before the scythe of death.' Emphasizing that not only was the World War 'a blow ... against capitalist civilization of the past, but against socialist civilization of the future,' she concluded: 'Here capitalism reveals its death's head, here it betrays that it has sacrificed its historic right of existence, that its rule is no longer compatible with the progress of humanity' (Luxemburg 1970, 325-326, 327).

Much has happened since Luxemburg wrote these lines. But what she had to say so many years ago has resonated in the subsequent history of the twentieth century, and in the realities of globalization that we face in the twenty-first.

\section{References}

Bronner, Stephen Eric Bronner, ed. 1993. The Letters of Rosa Luxemburg. New Edition. Atlantic Highlands: Humanities Press.

Bukharin, Nikolai. 1972. 'Imperialism and the Accumulation of Capital.' In Kenneth J. Tarbuck, ed., The Accumulation of Capital - An Anti-Critique by Rosa Luxemburg and Imperialism and the Accumulation of Capital by Nikolai Bukharin. New York: Monthly Review Press.

Bukharin, Nikolai. 1972a. Imperialism and World Economy. London: The Merlin Press.

Howard, M.C. and J.E. King. 1989. A History of Marxian Economics: Volume I, 1883-1929. Princeton: Princeton University Press.

Kowalik, Tadeusz. 1990. 'Rosa Luxemburg.' In John Eatwell, Murray Milgate, Peter Newman, eds., The New Palgrave Marxian Economics. New York: W.W. Norton. 
Lenin, Vladimir Illich. 2008. 'Imperialism, the Highest Stage of Capitalism,' In Paul Le Blanc, ed. V. I. Lenin, Revolution, Democracy, Socialism: Selected Writings. London: Pluto Press,.

Luxemburg, Rosa. 1951. The Accumulation of Capital. London: Routledge and Kegan Paul.

Luxemburg, Rosa. 1970. The Junius Pamphlet, in Rosa Luxemburg Speaks, ed. by Mary-Alice Waters New York: Pathfinder Press.

Magdoff, Harry. 1969. The Age of Imperialism: The Economics of U.S. Foreign Policy. New York: Monthly Review Press.

Marx, Karl. 1967. Capital, Vol. I. New York: International Publishers.

Rosdolsky, Roman. 1989. The Making of Marx's 'Capital.' Two volumes. London: Pluto Press.

Robinson, Joan. 1951. 'Introduction' in Rosa Luxemburg, The Accumulation of Capital. London: Routledge and Kegan Paul.

Sweezy, Paul M. 1968. The Theory of Capitalist Development .New York: Monthly Review Press. 